\title{
EFISIENSI TEKNIK PERBANKAN INDONESIA PASCAKRISIS EKONOMI: SEBUAH STUDI EMPIRIS PENERAPAN MODEL DEA
}

\author{
Adrian Sutawijaya ${ }^{1}$ \\ Etty Puji Lestari ${ }^{1}$ \\ ${ }^{1}$ Fakultas Ekonomi Universitas Terbuka Jakarta \\ Jalan Cabe Raya, Pondok Cabe Ciputat 15418 \\ E-mail: adriansutawijaya@yahoo.com
}

\begin{abstract}
This study analyzes the performance of the Indonesian banking sector efficiency and peeling technique factors that lead to inefficiencies that could reduce the bank's internal performance using Data Envelopment Analisys model (DEA). Research on the efficiency of banking techniques in Indonesia in 2000-2004 conducted using secondary data analysis including balance sheets and income statements of banks in Indonesia 12, the number of bank offices, and the number of bank employees in 2000 until 2004. Results of DEA analysis for the entire group decreased efficiency of banks during the crisis, except Bank Mandiri. This means that Bank Mandiri has the best performance compared to other banks. Inefficiency generally caused by using less than optimal inputs to produce output. Inputs that have not been completely allocated are assets and labor are not on optimizing the range below 50 percent. To produce the maximum efficiency, the bank must increase the use of its inputs to 100 percent.
\end{abstract}

Keywords: efisiensi perbankan, public expenditure and economic growth

\section{PENDAHULUAN}

Sektor keuangan di Indonesia mengalami perkembangan yang sangat pesat menjelang akhir 1980-an terutama setelah keluarkannya paket Kebijakan Juni 1983 (Pakjun 1983) dan Paket Kebijakan Oktober 1988 (Pakto 1988). Kedua kebijakan tersebut melatarbelakangi perkembangan industri perbankan sebagai salah satu industri keuangan di Indonesia. Peran perbankan sebagai lembaga perantara (financial intermediaries) dalam membiayai external financing (lihat Bodie dan Merton, 2000:418) terutama untuk investasi semakin bertambah. Jumlah bank meningkat dua kali lipat selama sepuluh tahun, yaitu dari 111 buah pada tahun 1988 menjadi 237 bank pada tahun 1997 (sebelum krisis), dan jumlah kantor bank meningkat lebih dari 200 persen, yaitu dari 1728 menjadi 6337 buah. Perkembangan sektor keuangan dapat dilihat dari peningkatan jumlah aset bank, kemampuan bank dalam mengumpulkan dana dan menyalurkan kredit yang meningkat lebih dari 500 persen sejak tahun 1989 sampai tahun 1996 (Laporan Bank Indonesia).

Rangkaian deregulasi yang dikeluarkan oleh pemerintah berdampak besar pada 
perubahan struktur perbankan nasional. Pasar keuangan semakin kompetitif. Banyaknya pembukaan bank dan kantor bank merupakan bukti bahwa bank adalah salah satu lembaga keuangan yang paling berkembang dalam merespon perubahan yang terjadi pada lembaga keuangan. Namun, deregulasi perbankan tanpa disertai dengan aturan kehatihatian (prudential regulation) serta pengawasan/supervisi yang memadai dapat berpengaruh buruk pada kinerja perbankan.

Perkembangan perbankan di Indonesia pada masa orde baru dibedakan menjadi dua, yaitu periode pra deregulasi (financial repression) dan periode pascaderegulasi (financial liberalism). Sebelum deregulasi 1983, kondisi perbankan ditandai oleh intervensi pemerintah yang sangat kuat, antara lain melalui penetapan suku bunga dan pagu kredit. Upaya memperbaiki sistem perbankan dari represif menjadi kompetitif mulai dilakukan pemerintah dengan penetapan deregulasi pada sektor keuangan. Melalui Pakjun 1983, pemerintah mulai menghapuskan sistem pagu suku bunga dan kredit dengan harapan dana masyarakat akan banyak diserap oleh perbankan apabila tingkat bunga menarik.

Krisis ekonomi dan keuangan yang awalnya melanda Thailand berdampak pada perekonomian negara-negara ASEAN, tak terkecuali Indonesia. Bahkan, kontraksi perekonomian Indonesia lebih besar dibanding negara lainnya. Kontraksi ekonomi di Indonesia pada tahun 1998 sebesar 13,7 persen, Malaysia -7,5 persen, Thailand -9,4 persen dan Korea Selatan sebesar $-5,8$ persen. Akibat krisis, sektor perbankan di Indonesia mengalami dampak yang paling parah. Menurut Adiningsih (2001), regulasi, supervisi dan sumber daya manusia yang ada belum mampu untuk menanggulangi perubahan perekonomian. Demikian juga dengan manajemen resiko likuiditas dan off balance sheet risk yang belum didayagunakan dengan baik, sehingga banyak bank yang memiliki open position yang tinggi terhadap valuta asing dan tingkat suku bunga. Sementara untuk bank asing, terjadinya krisis tidak terlalu membuat kondisi bank menurun secara signifikan seperti bank domestik, bahkan bisa dikatakan terjadinya krisis adalah keuntungan bagi mereka untuk menarik dana murah dari masyarakat akibat berkurangnya kepercayaan masyarakat terhadap bank domestik.

Penyalahgunaan kredit dan peraturan perbankan seperti CAR (capital asset ratio) dan net open position-pun tidak diterapkan dengan sungguh-sungguh. Akibatnya terjadi penurunan nilai rupiah, peningkatan suku bunga di atas ambang kewajaran dan menurunnya pertumbuhan ekonomi yang menyebabkan industri perbankan berada pada posisi yang sulit. Memburuknya kestabilan ekonomi tersebut terlihat dari tingginya jumlah kredit macet (non performing loan) dan rasio kecukupan modal (CAR) yang lebih rendah dari ketentuan yang telah ditetapkan oleh Bank Indonesia.

Spread negatif suku bunga rupiah hingga 15 persen pada tahun 1999 menyebabkan banyak bank mengalami kerugian dan CARnya menjadi negatif, sehingga perlu direstrukturisasi. Perbaikan yang utama dilakukan melalui penambahan permodalan terutama untuk bank-bank yang memiliki CAR antara -25 sampai dengan di bawah 4 persen. Namun demikian, usaha lain perlu dilakukan untuk memperbaiki bank agar dapat beroperasi dengan sehat dan efisien. Salah satu upaya meningkatkan efisiensi perbankan 
dilakukan dengan perbaikan manajerial, oleh karena itu diperlukan suatu teknik pengukuran yang tidak hanya menilai bobot kinerja tetapi juga mengukur sumber-sumber inefisiensi sehingga bisa diambil kebijakan koreksi internal dan eksternal oleh pihakpihak yang terkait dengan perbankan.

Perbankan sebagai salah satu lembaga keuangan yang memiliki peranan penting dituntut untuk memiliki kinerja yang baik. Salah satu aspek penting dalam pengukuran kinerja perbankan adalah efisiensi yang antara lain dapat ditingkatkan melalui penurunan biaya (reducing cost) dalam proses produksi. Berger, et al (1993), mengatakan jika terjadi perubahanan struktur keuangan yang cepat maka penting mengidentifikasikan efisiensi biaya dan pendapatan. Bank yang lebih efisien diharapkan akan mendapat keuntungan yang optimal, dana pinjaman yang lebih banyak, dan kualitas servis yang lebih baik pada nasabah.

Tingkat efisiensi yang dicapai merupakan cerminan dari kualitas kinerja yang baik. Pada dasarnya pengukuran kinerja sebuah lembaga keuangan hampir sama. Penilaian tingkat kesehatan dan produktivitas sebuah bank, asuransi dan LKBB dilakukan berdasarkan pada ketentuan peraturan perundangundangan yang berlaku. Pada sektor perbankan, lazimnya evaluasi tingkat kesehatan diukur menurut ketentuan yang ditetapkan oleh Bank Indonesia yang mengacu pada unsur-unsur modal (capital), kualitas aset (assets quality), manajemen (management), earning dan likuiditas (liquidity) atau CAMEL.
Beberapa pendapat menyimpulkan bahwa ukuran bank ${ }^{1}$ juga berpengaruh terhadap efisiensi. Penelitian yang dilakukan oleh Rangan, et.al (1988) menyatakan bahwa ukuran bank berpengaruh positip terhadap efisiensi. Artinya semakin besar suatu bank, akan semakin efisien, karena bank dapat memaksimalkan skala dan skup ekonomisnya. Hasil yang sama didapat dari penelitian Grabowski, et.al (1994), Aly, et.al (1990), Bodie dan Merton (2000), Miller dan Noulas (1996). Sementara penelitian yang dilakukan oleh Ferrier dan Lovell (1990), menyatakan sebaliknya. Menggunakan teknik programasi linier dan ekonometrika, mereka menyatakan bahwa bank yang kecil justru lebih efisien.

Penelitian ini akan menganalisis kinerja perbankan Indonesia dari sisi efisiensi teknik dan mengupas faktor-faktor yang menyebabkan terjadinya inefisiensi yang dapat menurunkan kinerja internal perbankan.

Selama ini kinerja bank diukur menggunakan standar akuntansi, misalnya dari return on equity (ROE), return on asset (ROA), asset turn over maupun return on permanent capital. Sementara dalam penelitian ini tidak menggunakan standar akuntansi, tetapi dengan Data Envelopment Analisys (DEA), sehingga diharapkan akan diperoleh sumbersumber inefisiensi pada manajerial perbankan dan diketahui faktor-faktor eksternal dan internal yang mempengaruhi terjadinya inefisiensi tersebut.

Pengukuran efisiensi sebenarnya tidak akan menghadapi kendala jika bank hanya memiliki satu input dan satu output saja untuk proses produksinya, namun hal demikian jarang dijumpai karena bank biasanya

1 Biasanya dilihat dari total nilai aset yang dimiliki (lihat Rose,1999:106, Sounders, 1999:290) 
memerlukan multi input dan menghasilkan berbagai output. Pengukuran efisiensi teknik yang menggunakan multi input dan output diharapkan akan memberi nuansa baru pada pengukuran kinerja perbankan dan dapat menjelaskan kinerja bank secara riil. Diharapkan dengan ditemukannya faktor penyebab inefisiensi maka dapat dilakukan kebijakan koreksi yang digunakan untuk meningkatkan kualitas kinerja bank. Penelitian ini akan mengukur efisiensi perbankan di Indonesia sebelum dan selama krisis.

Masalah efisiensi bukan merupakan masalah yang baru dalam dunia penelitian, baik efisiensi pada industri manufakturing, jasa maupun efisiensi pada lembaga keuangan, terutama sektor perbankan. Beberapa studi empiris terdahulu meneliti tentang efisiensi perbankan menggunakan pendekatan analisis yang berbeda, misalnya menggunakan ekonometrika, frontier stokhastik (stochastic frontier), thick frontier maupun Data Envelopment Analysis (DEA).

Penelitian ini mengacu pada penelitian yang dilakukan oleh Miller dan Noulas (1996). Mereka meneliti efisiensi perbankan di Amerika Serikat dari aspek profitabilitas menggunakan DEA dari sisi dualitasnya. Sementara penelitian ini menggunakan kasus Indonesia, dari sisi yang berbeda (primal) dengan beberapa pengembangan yang sesuai dengan karakteristik perbankan di Indonesia. Penelitian ini juga mencoba mencari sumber inefisiensi teknik perbankan membandingkan antar kelompok bank di Indonesia sebelum dan selama krisis berlangsung serta menganalisis faktor-faktor yang mempengaruhi terjadinya inefisiensi teknik pada perbankan Indonesia.

Salah satu cara mengukur kinerja perbankan adalah efisiensi yang dapat dilihat dari penggunaan input dan output yang digunakan untuk operasionalisasi bank. Secara umum kondisi perbankan di Indonesia belum semuanya efisien. Indikasi ini terlihat antara lain dari tingginya suku bunga kredit (prime rate) di Indonesia sebesar 18,5 persen pada tahun 1995, 16,75 persen tahun 1996 dan melonjak menjadi 39 persen pada tahun 1999 (FEER, beberapa edisi). Angka ini relatif tinggi jika dibandingkan dengan negara-negara di kawasan ASEAN. Malaysia, misalnya sebesar 7,3 persen (1995), 9 persen (1996), dan 8,03 persen (1999), serta Singapura sebesar 6 persen pada tahun 1995 dan 1996, serta 5 persen pada tahun 1999. Salah satu penyebab inefisiensi, antara lain diakibatkan oleh alokasi input yang kurang sempurna pada kegiatan operasionalisasi perbankan. Semakin efisien suatu bank maka kinerjanya semakin baik, sebaliknya bank yang mempunyai tingkat inefisiensi yang tinggi pada input dan outputnya, kinerjanya semakin menurun.

Tinjauan pustaka dalam penelitian ini sebagai berikut:

\section{Teori Efisiensi}

Pengertian efisiensi dapat dilihat dari berbagai sudut pandang yang berbeda. Efisiensi dapat didefinisikan sebagai rasio antara output dengan input (Kost dan Rosenwig, 1979:41). Ada tiga faktor yang menyebabkan efisiensi, yaitu apabila dengan input yang sama menghasilkan output yang lebih besar, dengan input yang lebih kecil menghasilkan output yang sama, dan dengan input yang besar menghasilkan output yang lebih besar. Sementara pendapat Tobin (lihat Fry, 1989:137-140, Permono dan Darmawan, 2000:1-13) ada empat faktor yang berpengaruh terhadap efisiensi perusahaan, pertama, 
efisiensi karena abitrase ekonomi, kedua, efisiensi karena ketepatan penilaian dasar aset-asetnya, ketiga, efisiensi karena lembaga keuangan bank mampu mengantisipasi resiko yang akan muncul dan keempat adalah efisiensi fungsional yang berkaitan dengan mekanisme pembayaran yang dilakukan oleh sebuah lembaga keuangan.

Ditinjau dari teori ekonomi, ada dua pengertian efisiensi, yaitu efisiensi teknik dan efisiensi ekonomi. Efisiensi ekonomis mempunyai sudut pandang makro yang mempunyai jangkauan lebih luas dibandingkan dengan efisiensi teknik yang bersudut pandang mikro. Pengukuran efisiensi teknik cenderung terbatas pada hubungan teknis dan operasional dalam proses konversi input menjadi output. Akibatnya, usaha untuk meningkatkan efisiensi teknis hanya memerlukan kebijakan mikro yang bersifat internal, yaitu dengan pengendalian dan alokasi sumber daya yang optimal. Dalam efisiensi ekonomis, harga tidak dapat dianggap given, karena harga dapat dipengaruhi oleh kebijakan makro (Walter, 1995, Sarjana, 1999).

Giuffrida dan Gravelle (2001), berpendapat bahwa ada tiga sumber inefisiensi biaya. Inefisiensi teknik (technical inefficiency) yang terjadi jika hanya sedikit output yang dihasilkan dari sejumlah input tertentu. Tingkat output unit kegiatan ekonomi (UKE) berada jauh di atas garis isokuan. inefisiensi alokasi (allocative inefficiency) terjadi ketika input digunakan dalam proporsi yang salah, sehingga harga dan produktivitas berada pada satu garis batas. UKE tetap berada pada garis isokuan, tetapi pada titik yang salah. Terakhir, skala inefisiensi (scale inefficiency) terjadi ketika biaya total dapat dikurangi dengan merubah jumlah UKE, dan unit kegiatan ekonomi berada pada garis isokuan yang salah.

\section{Teori Efisiensi Bank}

Kurva biaya rata-rata bank merupakan hubungan antara ukuran bank (biasanya dihitung dari nilai aset atau nilai simpanan) dengan biaya produksi output per-unit (lihat Rose,1999:106, Sounders, 1999:290). Kurva ini digambarkan berbentuk U-Shaped yang mendatar pada bagian tengahnya (Rose, 1999:106) yang mempunyai implikasi rentang bank yang menghasilkan efisiensi maksimal (lihat gambar 1).

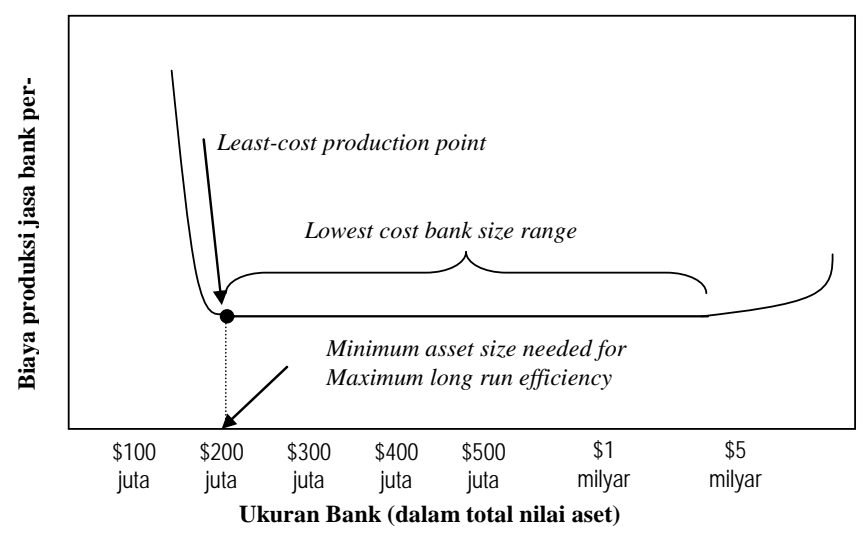

Gambar 1. Kurva Biaya Rata-rata Bank 
Beberapa penelitian menyatakan bahwa bank kecil memberikan pelayanan yang berbeda dengan bank besar, namun bank besar mampu memberikan jasa yang lebih lengkap. Implikasinya perhitungan biaya rata-rata yang dikeluarkan bank kecil berbeda dengan bank besar. Pada gambar 1, dinyatakan bahwa bank kecil dan menengah mencapai biaya produksi yang paling rendah, yaitu antara 100 juta dollar sampai 500 juta dollar AS pada nilai asetnya. Sebaliknya bank besar mencapai titik optimal (biaya terendah) antara 2 - 10 milyar dollar AS.

Awalnya, bank kecil (nilai aset $<100$ juta dollar AS) akan menanggung biaya produksi yang lebih banyak, tetapi cenderung menurun seiring bertambahnya aset. Pada aset 200 juta dollar AS, bank kecil berada pada titik biaya paling rendah (least cost production point). Penelitian terbaru yang dilakukan oleh Berger, et al (1996), menyatakan bahwa kebanyakan bank tidak beroperasi pada batas kemungkinan biaya minimumnya (minimum possible cost). Hasil penelitian menyatakan bahwa tingkat x-efficiency antara 20 sampai 25 persen lebih besar dari keseluruhan biaya produksi yang seharusnya terjadi pada kondisi efisiensi maksimum.

\section{Skala Ekonomis (economies of scale)}

Sebuah lembaga keuangan yang tumbuh pesat biasanya melakukan inovasi teknologi dan ekspansi usaha, sehingga biaya yang harus dikeluarkan meningkat. Untuk memaksimalkan keuntungan suatu bank harus melakukan efisiensi terutama untuk skala ekonomis (economies of scale) yaitu dengan meningkatkan output, agar biaya produksi yang dikeluarkan semakin menurun (Saunders, 1997:290). Umumnya, biaya produksi rata-rata (average cost) yang dikeluarkan oleh bank cenderung menurun seiring dengan ekspansi bank. Biaya rata-rata untuk memproduksi output diukur sebagai berikut:

$A C_{i}=\frac{T C_{i}}{S_{i}}$

dimana:

$A C_{i}=$ rata-rata biaya yang dikeluarkan bank i

$T C_{i}=$ biaya total yang dikeluarkan bank $\mathrm{i}$

$S_{i}=$ ukuran bank, dilihat dari aset, deposito dan pinjaman dari bank i

Efisiensi biaya bank dapat dilihat pada gambar 2 Bank yang berada di size $\mathrm{C}$ memiliki AC untuk pelayanan produksi yang relatif rendah dibandingkan bank pada size A atau $\mathrm{B}$, sehingga keuntungan yang didapat juga lebih tinggi. Bank $\mathrm{C}$ mempunyai kekuatan tawar menawar (bargaining power) yang lebih tinggi dibanding bank A atau B karena dapat memberikan pelayanan yang lebih baik dengan biaya yang lebih rendah.

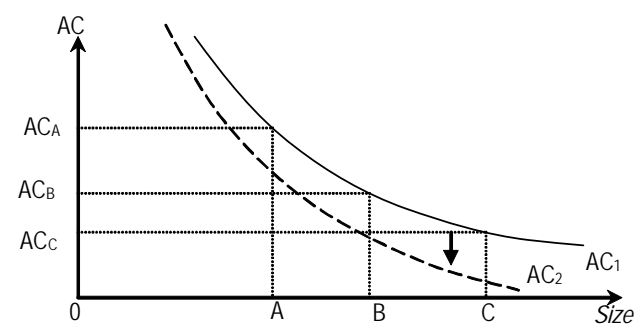

Sumber: Saunders (1997: 291)

\section{Gambar 2. Dampak Peningkatan Teknologi}

Implikasi skala ekonomis dalam jangka panjang, bahwa semakin besar suatu bank maka biaya rata-rata yang dikeluarkan akan semakin kecil dan efisien, terutama untuk peningkatan pelayanan produksi. Misalnya, 
penggunaan komputer dan satelit sabagai alat teknologi informasi diperlukan sebagai salah satu sarana untuk menekan biaya produksi. Dampak penggunaan teknologi yang dipakai untuk inovasi suatu bank ditunjukkan oleh perubahan penurunan kurva AC dan penurunan semakin besar apabila bank tumbuh semakin besar.

Pada gambar 2, kurva $\mathrm{AC}_{1}$ merupakan posisi awal sebelum penggunaan teknologi baru. $\mathrm{AC}_{2}$ merefleksikan adanya penurunan biaya rata-rata bank karena penggunaan teknologi baru. Penggunaan teknologi akan menggeser $\mathrm{AC}_{1}$ ke $\mathrm{AC}_{2}$ sehingga bank dapat menurunkan biaya rata-rata yang harus ditanggung. Kebalikannya, bank akan mengalami diseconomies of scale apabila untuk meningkatkan output, ongkos yang harus dikeluarkan bank semakin besar.

Menurut Martin (1988), skala ekonomis berbentuk kurva long run average cost (LAC) yang memiliki ekstrem minimum. Pada titik inilah perusahaan beroperasi pada ongkos produksi per-unit paling rendah atau minimum efficient of scale (MES) dan dari bawah kurva MC memotong kurva LAC dititik minimum.

Koefisien fungsi (function coefficient atau FC) yang digunakan dalam analisis ekonomi, merupakan perbandingan antara marginal cost dan average cost. Apabila $\mathrm{FC}=$ $\mathrm{AC} / \mathrm{MC}>1$, berarti perusahaan telah berproduksi pada skala economies of scale. Sementara jika $\mathrm{FC}=1$, biaya yang paling minimum dikeluarkan untuk menghasilkan barang yang diproduksi, tetapi jika $\mathrm{FC}<1$, maka perusahaan beroperasi pada diseconomies of scale.
MC, AC

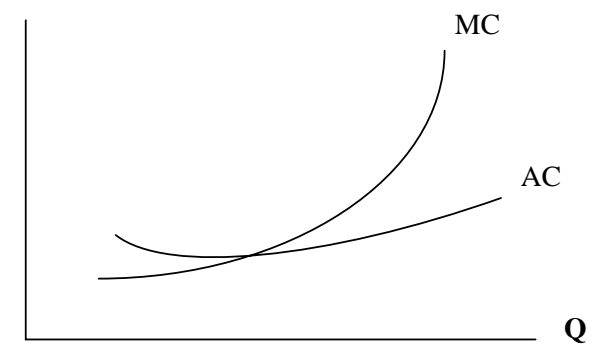

Sumber : Martin (1988:22)

Gambar 3. Economies dan Diseconomies of Scale

Ketika MC berada di bawah AC, maka tambahan biaya pemanfaatan input untuk menghasilkan tambahan satu unit output kurang dari besarnya biaya rata-rata per unit output, sehingga input lebih produktif selama terjadi penambahan output, ada peningkatan efisiensi. Sebaliknya ketika penambahan biaya input lebih besar dari biaya rata-rata maka harga output cenderung meningkat. Tambahan biaya ini merefleksikan adanya managerial loss of control pada perusahaan yang berskala besar dan mengakibatkan skala produksi tidak efisien.

\section{METODE PENELITIAN}

\section{Data dan Sumber Data}

Data yang akan digunakan dalam penelitian ini berasal Bank Indonesia, antara lain Direktori Bank Indonesia tahun 2000-2004, berupa neraca dan laporan laba rugi bank, Statistik Ekonomi dan Keuangan Indonesia beberapa edisi, dan Laporan Tahunan Bank Indonesia, serta hasil penelitian Biro Riset Infobank dan Asia Week.

Data yang digunakan dalam DEA, dibagi dalam variabel input dan output yang diformulasikan ke dalam dua asumsi yaitu constant return to scale (CRS) dan variable 
return to scale (VRS). Perhitungan efisiensi teknik dengan DEA menggunakan dua variabel input yaitu tenaga kerja dan aktiva perusahaan, serta dua variabel output meliputi pendapatan bunga dan pendapatan non bunga, masing-masing bank.

\section{Data Envelopment Analysis (DEA)}

DEA (Charnes, et.al (1978), Banker, et.al (1984)), adalah sebuah metode optimasi program matematika yang mengukur efisiensi teknik suatu unit kegiatan ekonomi (UKE) dan membandingkan secara relatif terhadap UKE yang lain. DEA mula-mula dikembangkan oleh Farrel (1957) yang mengukur efisiensi teknik satu input dan satu output, menjadi multi input dan multi output, menggunakan kerangka nilai efisiensi relatif sebagai rasio input (single virtual input) dengan output (single virtual output) (Giuffrida dan Gravelle,2001:4, Lewis,et.al 1999; 907-912, Post dan Spronk, 1999;3). Awalnya, DEA dipopulerkan oleh Charnes, Cooper dan Rhodes (1978) dengan metode constant return to scale (CRS) dan dikembangkan oleh Banker, Charnes, Cooper (1994) untuk variable return to scale (VRS), yang akhirnya terkenal dengan model CCR dan BCC.

DEA merupakan alat analisis yang digunakan untuk mengukur efisiensi, antara lain untuk penelitian kesehatan (healt care), pendidikan (education), transportasi, pabrik (manufacturing), maupun perbankan. Ada tiga manfaat yang diperoleh dari pengukuran efisiensi dengan DEA (Insukindro dkk, 2000:8), pertama, sebagai tolak ukur untuk memperoleh efisiensi relatif yang berguna untuk mempermudah perbandingan antar unit ekonomi yang sama. Kedua, mengukur berbagai variasi efisiensi antar unit ekonomi untuk mengidentifikasi faktor-faktor penyebabnya, dan ketiga, menentukan implikasi kebijakan sehingga dapat meningkatkan tingkat efisiensinya.

Awalnya, DEA digunakan untuk mengatasi kekurangan dimiliki oleh analisis rasio dan regresi berganda. Analisis rasio hanya mampu memberikan informasi bahwa UKE tertentu yang memiliki kemampuan khusus mengkonversi satu jenis input ke satu jenis output tertentu, sedangkan analisis regresi berganda menggabungkan banyak output menjadi satu. DEA dirancang untuk mengukur efisiensi relatif suatu unit kegiatan ekonomi (UKE) yang menggunakan input dan output yang lebih dari satu, dimana penggabungan tersebut tidak mungkin dilakukan. Efisiensi relatif suatu UKE adalah efisiensi suatu UKE dibanding dengan UKE lain dalam sampel yang menggunakan jenis input dan output yang sama. DEA memformulasikan UKE sebagai program linier fraksional untuk mencari solusi jika model tersebut ditransformasikan kedalam program linier dengan nilai bobot dari input dan output. UKE dipakai sebagai variabel keputusan (decision variables) menggunakan metode simplek.

Pada kasus input dan output yang bervariasi, efisiensi suatu UKE dihitung dengan mentransformasikan menjadi input dan output tunggal. Transformasi ini dilakukan dengan menentukan pembobot yang tepat. Penentuan pembobot ini yang selalu menjadi masalah dalam pengukuran efisiensi. DEA digunakan untuk menyelesaikan masalah dengan memberi kebebasan pada setiap UKE untuk menentukan pembobotnya masingmasing.

Konstruksi DEA yang didasarkan frontier data aktual pada sampel akan lebih 
efisien dibandingkan DEA yang tidak menggunakan frontier. Efisiensi UKE (Chilingerian, 1996) diukur dari rasio bobot output dibagi bobot input (total weighted output/total weighted input). Bobot tersebut memiliki nilai positif dan bersifat universal, artinya setiap UKE dalam sampel harus dapat menggunakan seperangkat bobot yang sama untuk mengevaluasi rasionya (total weighted/ total weighted input $\leq 1$ ). Angka rasio 1 (atau kurang dari satu) berarti UKE tersebut efisien (tidak efisien) dalam menghasilkan tingkat output maksimum dari tiap input. DEA berasumsi bahwa setiap UKE menggunakan kombinasi input yang berbeda untuk menghasilkan kombinasi output yang berbeda pula. Sehingga setiap UKE akan memilih seperangkat bobot yang mencerminkan keragaman tersebut. Secara umum UKE akan menetapkan bobot yang tinggi untuk input yang penggunaannya sedikit untuk memaksimalkan output, dan sebaliknya.

\section{Model Pengukuran Efisiensi Teknik Bank}

Efisiensi teknis perbankan diukur dengan menghitung rasio antara output dan input perbankan. Data Envelopment Analysis (DEA) akan menghitung bank yang menggunakan input $n$ untuk menghasilkan output $m$ yang berbeda (Miller dan Noulas;1996). Efisiensi bank diukur sebagai berikut:

$h_{s}=\sum_{i=1}^{m} u_{i} y_{i s} / \sum_{j=1}^{n} v_{j} x_{j s}$

dimana:

$h_{s} \quad$ adalah efisiensi teknik bank s

$y_{\text {is }}$ merupakan jumlah output $i$ yang diproduksi oleh bank s.

$\mathrm{x}_{\mathrm{js}}$ adalah jumlah input $\mathrm{j}$ yang digunakan oleh bank s $u_{i}$ merupakan bobot output i yang di hasilkan oleh bank $s$

$v_{j} \quad$ adalah bobot input j yang diberikan oleh bank $s$, dan $i$ dihitung dari 1 ke $m$ serta $j$ dihitung dari 1 ke $n$.

Persamaan di atas menunjukkan adanya penggunaan satu variabel input dan satu output. Rasio efisiensi $\left(h_{s}\right)$, kemudian dimaksimalkan dengan kendala sebagai berikut:

$$
\begin{aligned}
& \sum_{i=1}^{m} u_{i} y_{i r} / \sum_{j=1}^{n} v_{j} x_{j r} \leq 1 \text { untuk } \mathrm{r}=1, \ldots, \mathrm{N} \\
& U_{i} \operatorname{dan} V_{j} \geq 0
\end{aligned}
$$

dimana $\mathrm{N}$ menunjukkan jumlah bank dalam sampel. Pertidaksamaan pertama menunjukkan adanya efisiensi rasio untuk UKE lain tidak lebih dari 1 , sementara pertidaksamaan kedua berbobot positif. Angka rasio akan bervariasi antara 0 sampai dengan 1 . Bank dikatakan efisien apabila memiliki angka rasio mendekati 1 atau 100 persen, sebaliknya jika mendekati 0 menunjukkan efisiensi bank yang semakin rendah. Pada DEA, setiap bank dapat menentukan pembobotnya masing-masing dan menjamin bahwa pembobot yang dipilih akan menghasilkan ukuran kinerja yang terbaik.

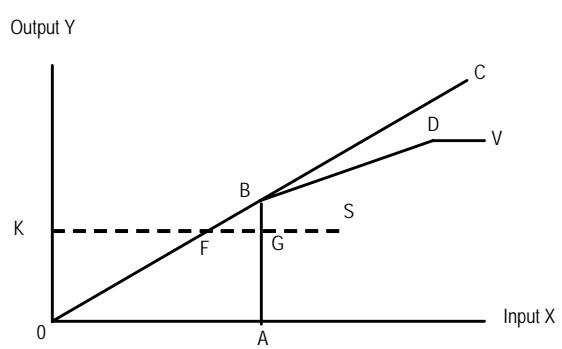

Sumber: Miller dan Noulas (1996)

Gambar 4. Pendekatan Satu Input dan Satu Output 
Gambar 4. menunjukkan adanya penggunaan satu variabel input dan satu output. Teknologi CRS ditunjukkan oleh frontier OC. Bank dikatakan efisien bila berada pada garis frontier, sedangkan yang berada di luar garis frontier dikatakan tidak efisien.

Beberapa bagian program linear ditransformasikan kedalam program ordinary linier secara primal atau dual sebagai berikut:

Maksimisasi $h_{s}=\sum_{i=1}^{m} u_{i} y_{i s}$

Kendala

$\sum_{i=1}^{m} u_{I} y_{i r}-\sum_{j=1}^{n} v_{j} x_{j} r \leq 0, r=1, \ldots \ldots . N$

$\sum_{j=1}^{n} v_{j} x_{j s}=1$ dan $u_{i}$ dan $v_{j} \geq 0$

Efisiensi pada masing-masing bank dihitung menggunakan programasi linier dengan memaksimumkan jumlah output yang dibobot dari bank s. Kendala jumlah input yang dibobot harus sama dengan satu untuk bank s, sedangkan kendala untuk semua bank, yaitu jumlah output yang dibobot dikurangi jumlah input yang dibobot harus kurang atau sama dengan 0 . Hal ini berarti semua bank akan berada atau dibawah referensi kinerja frontier yang merupakan garis lurus yang memotong sumbu origin (Insukindro, dkk, 2000:20).

Sementara jika teknologi dianggap variable return to scale, maka efisiensi berada pada garis ABDV. Dengan asumsi ini maka titik A,B,D, dan V dikatakan efisien. Programasi linier yang menunjukkan asumsi VRS adalah:
Maksimisasi $h_{s}=\sum_{i=1}^{m} u_{i} y_{i s}+U_{o}$

Kendala

$\sum_{i=1}^{m} u_{I} y_{i r}-\sum_{j=1}^{n} v_{j} x_{j} r \leq 0, r=1, \ldots \ldots . . N$;

$\sum_{j=1}^{n} v_{j} X_{j s}=1$ dan $u_{i}$ dan $v_{j} \geq 0$

dimana $U_{o}$ merupakan penggal yang dapat bernilai positif atau negatif. Transformasi juga dapat dilakukan secara dual dengan minimisasi input sebagai berikut:

Minimisasi $\beta_{s}$

Kendala $\sum_{r=1}^{n} \theta_{r} y_{i r} \geq y_{i s}, i=1, \ldots, m$

$\beta_{s} x_{j s}-\sum_{r=1}^{N} \theta_{r} x_{i r} \geq 0, j=1, \ldots ., n ; \theta_{r} \geq 0 ;$

dan $\beta$ s bebas

Variabel $\beta_{\mathrm{s}}$ merupakan efisiensi teknis dan bernilai antara 0 dan 1 . Programasi linier pada persamaan (7) dan (8) diasumsikan constant return to scale (CRS). Efisiensi teknis $\left(\beta_{\mathrm{s}}\right)$ diukur sebagai rasio $K F / K S$ dan bernilai kurang dari satu. Sementara (1- $\left.\beta_{\mathrm{s}}\right)$ menerangkan jumlah input yang harus dikurangi untuk menghasilkan output yang sama sebagai bentuk efisiensi bank seperti yang ditunjukkan oleh titik F. Kedua perhitungan, minimisasi input atau maksimisasi output, primal atau dual akan memberikan hasil yang relatif sama, sehingga dalam penelitian ini akan menghitung efisiensi dari satu sisi yaitu maksimisasi output. 
HASIL PENELITIAN DAN PEMBAHASAN

\section{Definisi dan Hubungan Antarvariabel yang Diamati}

Efisiensi merupakan salah satu pencerminan kinerja perbankan. Suatu bank dikatakan memiliki kinerja yang tinggi apabila dapat meningkatkan efisiensinya. Pemilihan variabel yang sesuai mutlak diperlukan agar pengukuran dapat memberikan hasil yang maksimal. Variabel yang digunakan dalam DEA dikelompokkan menjadi variabel input dan variabel output. Variabel input terdiri dari tenaga kerja dan aktiva perusahaan sedangkan dua variabel output adalah pendapatan bunga dan pendapatan non bunga.

Tenaga kerja merupakan variabel input, yaitu sumber daya manusia yang dihitung berdasarkan jumlah karyawan yang bekerja pada masing-masing bank pada tahun penelitian. Aktiva merupakan aset yang dimiliki oleh bank. Pendapatan bunga adalah pendapatan yang diterima oleh bank yang berasal dari bunga, sedangkan pendapatan non bunga merupakan pendapatan yang diterima oleh bank yang berasal selain dari bunga.

\section{Hasil Perhitungan Efisiensi Perbankan Dengan Metode Variable Return To Scale}

Hasil perhitungan efisiensi menggunakan Data Envelopment Analysis dengan metode variabel return to scale selengkapnya disajikan pada tabel 1. Hasil analisis menunjukkan bahwa pada tahun 2000 hanya 4 bank yang mencapai efisiensi kurang dari 100 persen, yaitu BNI (98,33 persen); BTN (99,27 persen), BII (87,55 persen) dan bank Niaga (66,78 persen). Bank yang memperoleh pencapaian efisiensi yang paling rendah adalah bank Niaga. Inefisiensi ini antara lain disebabkan oleh penggunaan input yang kurang optimal untuk menghasilkan output. Input yang belum dialokasikan sempurna adalah aktiva yang hanya dialokasikan sebesar 66,8 persen dan tenaga kerja yang masih digunakan 42,5 persen. Untuk menghasilkan efisien

Tabel 1. Hasil Efisiensi Perbankan dengan Metode VRS

\begin{tabular}{lrrrrrr}
\hline \multicolumn{1}{c}{ BANK } & $\mathbf{2 0 0 0}$ & $\mathbf{2 0 0 1}$ & $\mathbf{2 0 0 2}$ & $\mathbf{2 0 0 3}$ & $\mathbf{2 0 0 4}$ & $\begin{array}{c}\text { Pencapaian } \\
\text { rata-rata }\end{array}$ \\
\hline BANK PEMERINTAH & & & & & & \\
BRI & 100.00 & 25.22 & 16.01 & 79.20 & 100.00 & 64.09 \\
BNI & 98.33 & 100.00 & 43.91 & 100.00 & 100.00 & 88.45 \\
BTN & 99.27 & 65.01 & 48.99 & 100.00 & 88.21 & 80.30 \\
MANDIRI & 100.00 & 100.00 & 100.00 & 100.00 & 100.00 & 100.00 \\
BANK UMUM SWASTA NASIONAL & & & & \\
BCA & 100.00 & 7.33 & 24.92 & 48.95 & 50.23 & 46.29 \\
BII & 87.55 & 42.43 & 28.45 & 82.60 & 67.76 & 61.76 \\
NIAGA & 66.78 & 50.92 & 91.27 & 100.00 & 100.00 & 81.79 \\
DANAMON & 100.00 & 100.00 & 30.55 & 100.00 & 83.45 & 82.80 \\
BANK PEMBANGUNAN DAERAH & & & & & \\
BJATENG & 100.00 & 100.00 & 100.00 & 100.00 & 100.00 & 100.00 \\
BDKI & 100.00 & 100.00 & 100.00 & 100.00 & 100.00 & 100.00 \\
BJATIM & 100.00 & 80.90 & 88.13 & 100.00 & 95.19 & 92.84 \\
BJABAR & 100.00 & 83.01 & 71.85 & 100.00 & 100.00 & 90.97 \\
\hline
\end{tabular}


yang maksimal bank Niaga harus meningkatkan penggunaan inputnya masing-masing sebesar 33,2 dan 57,5 persen. Upaya peningkatan bisa dilakukan bank Niaga dengan mereferensikan pada BRI dan Bank Jabar.

Pada tahun 2001 kinerja perbankan banyak mengalami penurunan yang ditunjukkan oleh menurunnya pencapaian efisiensi oleh beberapa bank, bahkan BCA yang pada tahun 2000 sudah efisien, pada tahun 2001 mengalami penurunan efisiensi yang sangat signifikan yaitu sebesar 92,67 persen. Beberapa bank lain yang juga mengalami penurunan efisiensi adalah bank Jatim (-19,10 persen); bank Jabar (-16,99 persen), BRI (-74,78 persen); BTN (-34,26 persen), BII $(-45,12$ persen) dan bank Niaga $(15,86$ persen). Peningkatan efisiensi hanya dicapai oleh BNI yaitu dari 98,33 persen menjadi 100 persen. Penurunan yang sangat signifikan yang dialami oleh BCA diakibatkan belum dipergunakannya input secara maksimal. Aktiva hanya digunakan 7,3 persen sehingga untuk mencapai efisiensi harus ditingkatkan penggunaannya sebesar 92,7 persen. Sementara itu tenaga kerja hanya digunakan sebesar 7,3 persen sehingga untuk mencapai efisiensi maksimal harus ditingkatkan optimalitasnya sebesar 92,7 persen. Untuk Itu BCA dapat mereferensikan diri pada bank Danamon, bank Mandiri dan bank DKI untuk meningkatkan efisiensinya.

Pencapaian efisiensi pada tahun 2002 menunjukkan bahwa hanya tiga bank yang sudah mencapai efisiensi seratur persen. Ketiga bank tersebut adalah bank Mandiri, bank Jateng dan Bank DKI. Inefisiensi paling besar diperoleh BRI dengan pencapaian sebesar 16,01, menurun 9,21 persen dari tahun sebelumnya. Sumber inefisiensi terbesar berasal dari variabel aktiva yang hanya mencapai 15,4 persen dan tenaga kerja 16,0 persen. Untuk mencapai efisiensi 100 Untuk mencapai efisiensi 100 persen maka BRI harus meningkatkan penggunaan inputnya masing-masing sebesar 84,6 dan 84,0 persen. Hasil perhitungan untuk bank swasta diperoleh hasil bahwa semua bank swasta mengalami inefisiensi. Untuk meningkatkan efisiensi BRI dapat mengacu pada kinerja yang sudah dicapai oleh bank Mandiri dan bank DKI.

Hasil perhitungan dengan DEA pada tahun 2003 menunjukkan bahwa terjadi peningkatan efisiensi pada sembilan bank yang pada tahun 2002 mengalami inefisiensi. Bahkan beberapa bank peningkatan kinerjanya sangat signifikan dan mencapai 100 persen yaitu BNI, BTN, bank Niaga, Bank Danamon, Bank Jatim dan Bank Jabar. Pada tahun ini hanya tiga bank yang belum mencapai efisiensi maksimal (100 persen) antara lain BRI, BCA dan BII. Hasil ini sejalan dengan temuan Ferrier dan Lovell (1990) yang mengevaluasi efisiensi 575 bank di Amerika Serikat pada tahun 1984 yang menyatakan bahwa bank besar justru yang lebih sulit untuk mencapai efisiensi maksimal.

Hasil pencapaian efisiensi pada tahun 2004 menyatakan bahwa ada lima bank yang belum mencapai efisiensi maksimal yaitu BTN, BCA, BII dan bank Danamon. Jika dibandingkan dengan pencapaian tahun 2003 maka hanya BRI yang mengalami peningkatan efisiensi, sedangkan empat bank diatas mengalami penurunan efisiensi.. Pencapaian efisiensi terkecil dicapai BCA dengan nilai efisiensi hanya 50,23 persen.

Dilihat dari pencapaian secara rata-rata maka bank umum swasta nasional memiliki tingkat efisiensi paling rendah yaitu berkisar 
antara 46 sampai 82 persen, bahkan tidak satupun bank swasta yang dipakai sebagai sampel yang memiliki efisiensi maksimal 100 persen. Untuk itu bank swasta harus lebih meningkatkan kinerja agar bisa bersaing dengan bank pemerintah dan bank pembangunan. Dari pencapaian tingkat efisiensi secara keseluruhan tersebut maka dapat disimpulkan bahwa ternyata tingkat efisiensi bank pembangunan daerah secara rata-rata paling tinggi dibandingkan bank pemerintah dan bank swasta. Hasil ini sesuai dengan kajian yang dilakukan Ferrier dan Lovell (1990), yang menyatakan bahwa bank yang kecil justru lebih efisien dibandingkan bank besar.

\section{Hasil Analisis Tiap Variabel dengan Metode VRS}

Hasil pencapaian efisiensi tiap variabel dengan metode variable return to scale selengkapnya dapat dilihat pada tabel 2 .
Temuan ini menunjukkan bahwa rata-rata tiap variabel menunjukkan bahwa tenaga kerja merupakan variabel yang memiliki nilai efisiensi rata-rata paling rendah yaitu sebesar 39.08 persen disusul oleh aktiva dengan nilai rata-rata 43,70 persen. Rendahnya pencapaian nilai efisiensi tersebut antara lain disebabkan bank kelebihan tenaga kerja yang dipekerjakan sehingga menurunkan optimalitas pekerja. Persoalan tenaga kerja memang menjadi salah satu permasalahan rumit dalam perekonomian. Meningkatnya supply tenaga kerja yang tidak diimbangi oleh luasnya lapangan pekerjaan menimbulkan masalah. Pada kasus yang dialami bank, peningkatan jumlah tenaga kerja yang tidak diimbangi dengan skill yang memadai akan menyebabkan bank mengalami penurunan produktivitas. Hal ini sesuai dengan law of diminishing marginal return, dimana penambahan tenaga kerja justru akan menyebabkan penurunan marginal tenaga kerja

Tabel 2. Hasil Efisiensi tiap Variabel dengan Metode VRS

\begin{tabular}{|c|c|c|c|c|}
\hline BANK & AKTIVA & TENAGA KERJA & PENDAPATAN BUNGA & PENDAPATAN NON BUNGA \\
\hline \multicolumn{5}{|c|}{ BANK PEMERINTAH } \\
\hline $\begin{array}{l}\text { BRI } \\
\text { BNI } \\
\text { BTN } \\
\text { MANDIRI }\end{array}$ & $\begin{array}{r}63.96 \\
82.50 \\
74.54 \\
100.00\end{array}$ & $\begin{array}{r}56.36 \\
88.44 \\
80.30 \\
100.00\end{array}$ & $\begin{array}{r}65.36 \\
82.50 \\
83.54 \\
100.00\end{array}$ & $\begin{array}{r}97.38 \\
100.00 \\
91.50 \\
100.00\end{array}$ \\
\hline \multicolumn{5}{|c|}{ BANK UMUM SWASTA NASIONAL } \\
\hline $\begin{array}{l}\text { BCA } \\
\text { BII } \\
\text { NIAGA } \\
\text { DANAMON }\end{array}$ & $\begin{array}{l}43.70 \\
60.54 \\
79.24 \\
80.94\end{array}$ & $\begin{array}{l}39.08 \\
56.88 \\
75.24 \\
82.78\end{array}$ & $\begin{array}{l}83.50 \\
65.94 \\
61.12 \\
80.92\end{array}$ & $\begin{array}{r}87.32 \\
100.00 \\
92.26 \\
100.00\end{array}$ \\
\hline \multicolumn{5}{|c|}{ BANK PEMBANGUNAN DAERAH } \\
\hline $\begin{array}{l}\text { BJATENG } \\
\text { BDKI } \\
\text { BJATIM } \\
\text { BJABAR } \\
\text { Minimum } \\
\text { Maksimum }\end{array}$ & $\begin{array}{r}100.00 \\
100.00 \\
92.84 \\
90.56 \\
43.70 \\
100.00\end{array}$ & \begin{tabular}{r|}
100.00 \\
100.00 \\
92.84 \\
90.98 \\
39.08 \\
100.00
\end{tabular} & $\begin{array}{r}100.00 \\
100.00 \\
91.74 \\
78.72 \\
61.12 \\
100.00\end{array}$ & $\begin{array}{r}100.00 \\
100.00 \\
81.24 \\
100.00 \\
81.24 \\
100.00\end{array}$ \\
\hline
\end{tabular}


Sementara itu nilai efisiensi rata-rata antar variabel terbesar dicapai oleh pendapatan non bunga dengan tingkat pendapatan efisiensi sebesar 81,24 persen. Kondisi ini sesuai dengan fakta yang terjadi bahwa saat ini ada kecenderungan bank untuk memperoleh pendapatan diluar bunga antara lain dengan menerbitkan kartu pastik dengan berbagai fasilitas kemudahan yang berguna untuk menarik minat konsumen. Saat ini yang paling banyak ditawarkan adalah kartu kredit dan ATM. Fleksibilitas dalam pembayaran dan angsuran menyebabkan kartu plastik banyak diminati masyarakat karena masyarakat tidak perlu lagi membawa uang tunai dalam jumlah yang besar apabila ingin melakukan wisata atau kunjungan ke negara lain dalam jangka waktu lama. Pertumbuhan kartu plastik memberikan dampak pemasukan yang signifikan pada pendapatan non bunga bank.
Hasil Perhitungan Efisiensi Perbankan dengan Metode Constant Return to Scale

Hasil analisis dengan metode constant return to scale menunjukkan bahwa pada tahun 2000 bank yang memiliki efisiensi paling kecil adalah Bank Pembangunan Daerah DKI atau yang lebih dikenal dengan bank DKI yaitu sebesar 12,86 persen (lihat tabel 3). Sementara bank yang sudah mencapai efisiensi 100 persen ada 5 bank yaitu Bank Rakyat Indonesia (BRI), bank mandiri, BCA, bank danamon dan bank jabar. Inefisiensi bank DKI ini disebabkan oleh alokasi input yang kurang maksimal untuk memperoleh output. Variabel yang belum dialokasikan maksimal adalah aktiva yang masih mencapai 7,3 persen dan harus ditingkatkan penggunaan inputnya sebesar 92,7 persen. Pada aktiva ini terjadi pemborosan aset karena target efisiensi seharusnya 4.542 .969 .9 ribu namun dialokasikan sebesar 62159479.0 ribu. Penggunaan tenaga kerja juga demikian. Seharusnya bank Jabar mempekarjakan 116 karyawan, namun yang terjadi jumlah

Tabel 3. Hasil Efisiensi Perbankan dengan Metode Constant Return to Scale

\begin{tabular}{lrrrrrr}
\hline \multicolumn{1}{c}{ BANK } & $\mathbf{2 0 0 0}$ & $\mathbf{2 0 0 1}$ & $\mathbf{2 0 0 2}$ & $\mathbf{2 0 0 3}$ & $\mathbf{2 0 0 4}$ & $\begin{array}{c}\text { Pencapaian } \\
\text { Rata-rata }\end{array}$ \\
\hline BANK PEMERINTAH & & & & & & \\
BRI & 100.00 & 24.04 & 14.89 & 64.15 & 98.93 & 60.40 \\
BNI & 98.27 & 100.00 & 42.39 & 80.54 & 82.73 & 80.78 \\
BTN & 92.37 & 45.22 & 36.78 & 84.58 & 78.95 & 67.58 \\
MANDIRI & 100.00 & 100.00 & 100.00 & 94.83 & 100.00 & 98.96 \\
BANK UMUM SWASTA NASIONAL & & & & \\
BCA & 100.00 & 3.45 & 23.37 & 36.37 & 43.60 & 41.36 \\
BII & 86.94 & 32.19 & 22.07 & 74.99 & 66.63 & 56.56 \\
NIAGA & 66.27 & 39.50 & 88.11 & 100.00 & 100.00 & 78.77 \\
DANAMON & 100.00 & 11.05 & 26.50 & 85.50 & 81.53 & 60.92 \\
BANK PEMBANGUNAN DAERAH & & & & \\
BJATENG & 91.50 & 13.50 & 8.96 & 99.69 & 100.00 & 62.73 \\
BDKI & 12.86 & 20.77 & 20.56 & 84.88 & 91.32 & 46.09 \\
BJATIM & 95.14 & 13.05 & 9.93 & 100.00 & 87.99 & 61.22 \\
BJABAR & 100.00 & 19.05 & 24.57 & 100.00 & 100.00 & 68.72 \\
\hline \multicolumn{7}{c}{} \\
\hline
\end{tabular}


tenaga kerja yang digunakan sebesar 903 orang sehingga terjadi pemborosan tenaga kerja. Upaya untuk meningkatkan efisiensi dapat dilakukan bank DKI dengan mengefisiensikan penggunaan input. Sebagai acuan, bank DKI bisa memilih BCA dan Bank danamon yang sudah memiliki nilai efisiensi 100 persen.

Pencapaian efisiensi pada tahun 2001 menunjukkan bahwa hanya dua bank yang sudah mencapai efisiensi seratus persen yakni Bank Mandiri dan Bank Negara Indonesia (BNI). Sementara bank yang memiliki efisiensi paling kecil adalah BCA sebesar 3,45 persen. Inefisiensi BCA ini disebabkan oleh alokasi input yang kurang maksimal untuk mendapatkan ouput. Variabel yang belum dialokasikan maksimal adalah aktiva yang masih mencapai 1,6 persen dan harus ditingkatkan penggunaan inputnya sebesar 98,4 persen. Sedangkan aktiva ini terjadi pemborosan aset karena target efisiensi seharusnya 1606867.3 ribu namun dialokasikan sebesar 103032534.0 ribu. Penggunaan tenaga kerja juga demikian. Seharusnya BCA mempekerjakan 739.8 karyawan, namun yang terjadi jumlah tenaga kerja yang digunakan sebesar 21413.0 orang sehingga terjadi pemborosan tenaga kerja. Upaya untuk meningkatkan efisiensi dapat dilakukan BCA dengan mengefisiensikan penggunaan input. Sebagai acuan, BCA bisa Bank Mandiri dan Bank Negara Indonesia (BNI) yang sudah memiliki nilai efisiensi 100 persen. Upaya untuk meningkatkan efisiensi dapat dilakukan BCA dengan mengefisiensikan penggunaan input. Sebagai acuan, BCA bisa Bank Mandiri dan Bank Negara Indonesia (BNI)yang sudah memiliki nilai efisiensi 100 persen.
Hasil analisis dengan metode constant return to scale menunjukkan bahwa pada tahun 2002 bank yang memiliki efisiensi paling kecil adalah Bank Jateng yaitu sebesar 8,96 persen dan Bank Jatim sebesar 9,93\%. Sementara bank yang mencapai efisiensi 100 persen hanya 1 bank yaitu Bank Mandiri. Banyaknya Inefisiensi pada tahun 2002 ini disebabkan oleh alokasi input yang kurang maksimal untuk memperoleh output. Variabel yang belum dialokasikan maksimal yakni pada Bank Jateng aktiva yang masih mencapai 6,3 persen dan harus ditingkatkan penggunaan inputnya sebesar 93,7 persen. Pada aktiva ini terjadi pemborosan aset karena target efisiensi seharusnya 322805.3 ribu namun dialokasikan sebesar 5109753.0 ribu. Penggunaan tenaga kerja juga demikian. Seharusnya Bank Jateng mempekerjakan 156.2 karyawan, namun yang terjadi jumlah tenaga kerja yang digunakan sebesar 1744 orang sehingga terjadi pemborosan tenaga kerja. Kemudian pada Bank Jatim Variabel yang belum dialokasikan maksimal yakni variabel aktiva yang masih mencapai 2,6 persen dan harus ditingkatkan penggunaan inputnya sebesar 97,4 persen. Pada aktiva ini terjadi pemborosan aset karena target efisiensi seharusnya 163269.0 ribu namun dialokasikan sebesar 6386132.0 ribu. Penggunaan tenaga kerja juga demikian. Seharusnya Bank Jatimg mempekerjakan 79 karyawan, namun yang terjadi jumlah tenaga kerja yang digunakan sebesar 796 orang sehingga terjadi lagi pemborosan tenaga kerja. Upaya untuk meningkatkan efisiensi dapat dilakukan bank Jateng dan bank Jatim dengan mengefisiensikan penggunaan input. Sebagai acuan, bisa memilih Bank Mandiri yang sudah memiliki nilai efisiensi 100 persen. 
Pencapaian efisiensi pada tahun 2003 menunjukkan bahwa ada tiga bank yang sudah mencapai efisiensi seratus persen yakni Bank Niaga, Bank Jabar dan Bank Jatim. Sementara bank yang memiliki efisiensi paling kecil adalah BCA sebesar 36,37 persen. Inefisiensi BCA ini disebabkan oleh alokasi input yang kurang maksimal untuk mendapatkan ouput. Variabel yang belum dialokasikan maksimal adalah aktiva yang masih mencapai 36,4 persen dan harus ditingkatkan penggunaan inputnya sebesar 63,6 persen. Sedangkan aktiva ini terjadi pemborosan aset karena target efisiensi seharusnya 48355066,3 ribu namun dialokasikan sebesar 132969372,0 ribu. Penggunaan tenaga kerja juga demikian. Seharusnya BCA mempekerjakan 5581 karyawan, namun yang terjadi jumlah tenaga kerja yang digunakan sebesar 21367,0 orang sehingga terjadi pemborosan tenaga kerja. Upaya untuk meningkatkan efisiensi dapat dilakukan BCA dengan mengefisiensikan penggunaan input. Sebagai acuan, BCA bisa Bank Mandiri dan Bank Negara Indonesia (BNI) yang sudah memiliki nilai efisiensi 100 persen. Upaya untuk meningkatkan efisiensi dapat dilakukan BCA dengan mengefisiensikan penggunaan input. Sebagai acuan, BCA bisa memilih Bank Niaga, Bank Jatim dan Bank Jabar yang sudah memiliki nilai efisiensi 100 persen.

Hasil perhitungan dengan DEA pada tahun 2004 menunjukkan bahwa terjadi efisiensi pada empat bank yakni Bank Mandiri, Bank Niaga, Bank Jateng dan Bank jabar. Bahkan bank Mandiri yang pada tahun 2003 tingkat efisiensinya menurun pada tahun 2004 peningkatan kinerjanya meningkat sampai 100 persen. Pada tahun ini bank yang pencapaian efisiensi terkecil adalah
BCA. Hasil ini sejalan dengan temuan Ferrier dan Lovell (1990) yang mengevaluasi efisiensi 575 bank di Amerika Serikat pada tahun 1984 yang menyatakan bahwa bank besar justru yang lebih sulit untuk mencapai efisiensi maksimal.

\section{Hasil Analisis Tiap Variabel dengan Metode CRS}

Hasil pencapaian efisiensi tiap variabel dengan metode constant return to scale selengkapnya dapat dilihat pada tabel 4. memperlihatkan bahwa rata-rata tiap variabel yang diamati menunjukkan bahwa tenaga kerja merupakan variabel yang memiliki nilai efisiensi rata-rata paling rendah yaitu sebesar 37,44 persen disusul oleh aktiva dengan nilai rata-rata 38,08 persen.

Pada tabel 4, dengan menggunakan metode constant return to scale menunjukkan variabel tenaga kerja merupakan variabel yang memiliki nilai efisiensi rata-rata paling rendah yaitu sebesar 37,44 persen disusul oleh aktiva dengan nilai rata-rata 38,08 persen. Rendahnya pencapaian nilai efisiensi tersebut antara lain disebabkan bank kelebihan tenaga kerja yang dipekerjakan sehingga menurunkan optimalitas pekerja. Persoalan tenaga kerja memang menjadi salah satu permasalahan rumit dalam perekonomian. Meningkatnya supply tenaga kerja yang tidak diimbangi oleh luasnya lapangan pekerjaan menimbulkan masalah. Pada kasus yang dialami bank, peningkatan jumlah tenaga kerja yang tidak diimbangi dengan skill yang memadai akan menyebabkan bank mengalami penurunan produktivitas. Hal ini sesuai dengan law of diminishing marginal return, dimana penambahan tenaga kerja justru akan menyebabkan penurunan marginal tenaga kerja 
Tabel 4. Hasil Analisis Rata-rata tiap Variabel dengan Metode CRS

\begin{tabular}{lcrrr}
\hline \multicolumn{1}{c}{ Bank } & Aktiva & Tenaga Kerja & Pendapatan Bunga & \multicolumn{2}{c}{$\begin{array}{c}\text { Pendapatan } \\
\text { non bunga }\end{array}$} \\
\hline BANK PEMERINTAH & & & \\
BRI & 59.62 & 50.80 & 65.32 & 97.18 \\
BNI & 74.68 & 75.08 & 81.28 & 95.40 \\
BTN & 62.28 & 57.68 & 81.28 & 95.40 \\
MANDIRI & 92.86 & 98.96 & 100.00 & 100.00 \\
BANK UMUM & SWASTA NASIONAL & & \\
BCA & 38.08 & 39.32 & 83.46 & 88.76 \\
BII & 53.88 & 47.56 & 65.66 & 100.00 \\
NIAGA & 72.32 & 71.76 & 61.08 & 100.00 \\
DANAMON & 55.82 & 51.18 & 80.90 & 86.92 \\
BANK PEMBANGUNAN DAERAH & & \\
BJATENG & 62.20 & 37.44 & 63.52 & 100.00 \\
BDKI & 40.18 & 46.10 & 72.40 & 93.76 \\
BJATIM & 59.76 & 58.66 & 71.82 & 90.08 \\
BJABAR & 65.76 & 68.72 & 70.94 & 100.00 \\
Minimum & $\mathbf{3 8 . 0 8}$ & $\mathbf{3 7 . 4 4}$ & 61.08 & $\mathbf{8 6 . 9 2}$ \\
Maksimum & $\mathbf{9 2 . 8 6}$ & $\mathbf{9 8 . 9 6}$ & $\mathbf{1 0 0 . 0 0}$ & 100.00 \\
\hline
\end{tabular}

Sementara itu nilai efisiensi rata-rata antar variabel terbesar dicapai oleh pendapatan bunga dan pendapatan non bunga dengan tingkat pendapatan efisiensi sebesar 100 persen. Kondisi ini sesuai dengan fakta yang terjadi bahwa saat ini ada kecenderungan bank untuk memperoleh pendapatan diluar bunga antara lain dengan menerbitkan kartu pastik dengan berbagai fasilitas kemudahan yang berguna untuk menarik minat konsumen. Saat ini yang paling banyak ditawarkan adalah kartu kredit dan ATM. Fleksibilitas dalam pembayaran dan angsuran menyebabkan kartu plastik banyak diminati masyarakat karena masyarakat tidak perlu lagi membawa uang tunai dalam jumlah yang besar apabila ingin melakukan wisata atau kunjungan ke negara lain dalam jangka waktu lama. Pertumbuhan kartu plastik memberikan dampak pemasukan yang signifikan pada pendapatan non bunga bank.

\section{KESIMPULAN}

Penelitian efisiensi teknis perbankan di Indonesia yang dilakukan terhadap 12 bank yang ada di Indonesia, menggunakan DEA-CRS, dan DEA-VRS, memberikan kesimpulan sebagai berikut.

1. Perhitungan DEA untuk efisiensi teknik dengan asumsi teknologi VRS dan teknologi CRS. Umumnya rata-rata pencapaian efisiensi setiap variabel mengalami penurunan. Kenyataannya, pada saat krisis, bank cenderung mengadakan efisiensi, agar biaya yang dikeluarkan menurun. Hal ini dilakukan karena selama krisis fungsi bank sebagai financial intermediary tidak berjalan normal, akibatnya, pendapatan bank menurun. Sumber inefisiensi terbesar untuk seluruh bank terletak pada tenaga kerja dengan pencapaian efisiensi ratarata sebesar 37,44 persen (CRS), dan 
39,08 persen (VRS), artinya rata-rata bank belum memaksimalkan pemanfaatan inputnya. Untuk mencapai efisiensi maksimal, bank harus menambah penggunaan inputnya sebesar 62,56 (CRS) dan 60,92 (VRS) persen.

2. Hasil analisis DEA untuk tiap kelompok bank, seluruh kelompok bank mengalami penurunan efisiensi selama krisis, kecuali bank mandiri. Ini berarti bank mandiri memiliki performance paling bagus dibandingkan bank lainnya. Indikasi ini terlihat dari rendahnya prosentase penurunan efisiensi dengan asumsi CRS dan asumsi VRS.

Dari kesimpulan di atas, dapat diajukan beberapa kebijakan koreksi agar tercipta struktur perbankan yang tangguh dan efisien sehingga mampu bersaing dalam globalisasi pasar keuangan.

1. Untuk itu kasus yang dialami bank yaitu kelebihan tenaga kerja harus segera diselesaikan agar bank bisa mengoptimalkan penggunaan input tenaga kerjanya dalam menghasilkan output yang optimal. Rekomendasi kebijakan yang disarankan adalah adanya aturan internal bank untuk menggunakan sistem kontrak untuk pegawainya. Saat ini banyak bank yang sudah menerapkan sistem kontrak yang bisa diperbaharui setiap dua tahun sekali. Dengan demikian bank bisa mengefisienskan penggunaan tenaga kerjanya karena jika bank merasa karyawan tidak memiliki skill dan kemampuan yang cukup maka bank dapat menghentikan atau mem PHK karyawan

2. Upaya perbaikan efisiensi dapat dilakukan dengan meningkatkan penggunaan input secara lebih efisien. Pendapatan non bunga misalnya, merupakan penerimaan paling potensial bagi bank yang dapat memberikan nilai tambah bagi peningkatan efisiensi perbankan, untuk itu bank perlu terus meningkatkan penerimaan Pendapatan non bunga agar tercapai efisiensi yang maksimal. Upaya lain perlu dilakukan, antara lain dengan meningkatkan produk-produk pelayanan jasa bank, mengingat sektor perbankan rentan terhadap perubahan struktur ekonomi. Perbankan di Indonesia masih ada indikasi ketergantungan mendapatkan penghasilan dari suku bunga (interest rate based income) dan bukan dari komisi jasa (fee based income). Realisasinya bisa dilakukan dengan ATMmisasi perbankan, go public, pemberian kredit properti dan konsumsi ataupun dengan pembuatan kartu kredit.

Pemerintah dan pihak perbankan perlu membenahi kembali program restrukturisasi dan privatisasi, terutama untuk bank-bank yang belum efisien, sehingga akan lebih kompetitif. Misalnya melalui proses penambahan modal, meningkatkan kemampuan teknis, manajerial, operasional dan skill terutama untuk sumber daya manusianya. Restrukturisasi perbankan di Indonesia sebenarnya pernah digulirkan sejak bulan November 1997, namun berjalan sangat lambat sehingga membawa dampak yang luas. Selain akan meningkatkan biaya restrukturisasi juga akan memperlambat penyehatan sektor korporasi dan perekonomian secara keseluruhan. Untuk itu usaha restrukturisasi perlu dilanjutkan kembali dengan penanganan yang lebih intensif, karena penyehatan perbankan akan berpengaruh terhadap penyehatan perekonomian di Indonesia. 


\section{DAFTAR PUSTAKA}

Adiningsih, S., 2001, Masalah dan Tantangan yang Dihadapi dalam Rangka Mengembangkan Regulasi Perbankan yang Sehat, Makalah Workshop.

Aly, H.Y., Grabowski. R., Pasurka. C., and N. Rangan., 1990, Technical, Scale and Allocative Efficiencies in U.S. Banking: An Empirical Investigation, Review of Economic and Statistics 72, 211-218.

Bank Indonesia, Statistik Ekonomi dan Keuangan Indonesia, beberapa edisi.

Berger, A.N., Hunter. W.C.,and Time,S.G., 1993, The Efficiency of Financial Institution, A Review and Preview of Research Past, Present and Future, Journal of Banking and Finance, No.17, 221-249.

Bodie, Zvi., and Merton, Robert, C., (2000), Finance, International Edition, Prentice Hall International.Inc, USA. P.410-420.

Far Eastern Economic Review, beberapa edisi

Ferier,G.D., and. Lovell, C.A.K., 1990, Measuring Cost Efficiency in Banking, Econometric and Linear Programming Evidence, Journal of Econometric, 46, 229-245.

Grabowski, R.N. Rangan, and Rezvanian, R., 1994, Organizational Form in Banking: an Empirical Investigation of Cost Efficiency”, Journal of Banking Finance 17, 531-538.

Gujarati, Damodar.N., 1995, Basic Econometrics, New York: Mc Graw-Hill Inc.

Insukindro, Nopirin, Makhfatih,A., Ciptono, S.M., 2000. Laporan Akhir Pengukuran Efisiensi Relatif Pelayanan Kantor Cabang Pegadaian, Yogyakarta: Pene- litian dan Pengembangan Manajemen (PPM) Fakultas Ekonomi Universitas Gadjah Mada.

Miller. S.M., and Noulas.A.G., 1996, The Technical Efficiency of Large Bank Production, Journal of Banking and Finance 20, 495-509.

Pindyck, R.S., and Rubinfeld, Daniel, L., 1998, Econometric Models and Economic Forecasts, International Edition, USA: McGraw-Hill Companies.

Rose, Peter.S., 1999, Commercial Bank Management, fourth edition, USA: Mc.Graw Hill International Edition, p.106-108.

Saunders, A., 1997, Operating Cost and Technology Risk, Financial Institutional Management, Irwin McGraw Hill, Second Edition, 247-275. 